\title{
Pengambilan Data Terbang Quadcopter sebagai Data Latih pada Sistem Kendali Jaringan Saraf Tiruan Propagasi Balik
}

\section{Quadcopter Flight Data Acquisition as a Training Data for Backpropagation Neural Network Control Systems}

\author{
MUHAMMAD HAZIM $^{1}$, KARLISA PRIANDANA $^{1 *}$, WULANDARI $^{1}$
}

\begin{abstract}
Abstrak
Saat ini sistem kendali yang populer digunakan pada quadcopter adalah kendali proportional, integral, derivate (PID) karena algoritme tersebut sederhana. Namun pada implementasinya, PID membutuhkan penyetelan parameter yang memakan waktu dan rentan terhadap kesalahan. Oleh karena itu, sistem kendali jaringan saraf tiruan propagasi balik untuk quadcopter saat ini mulai banyak dikembangkan karena menawarkan stabilisasi yang lebih baik dari faktor-faktor yang tidak diketahui dan data sensor yang mengandung noise. Akan tetapi, sistem kendali jaringan saraf tiruan propagasi balik memerlukan data latih yang akurat dan dapat mewakili seluruh kemungkinan kondisi terbang quadcopter. Penelitian ini bertujuan untuk memperoleh data terbang quadcopter dari data $\log$ sensor dan aktuator yang ada di quadcopter, yaitu giroskop, akselerometer, magnetometer, barometer, GPS, dan pulse width modulation output. Pengambilan data dilakukan dengan menerbangkan quadcopter secara otomatis dengan koordinat awal dan akhir yang telah ditentukan untuk mengisi data log terbang. Data log terbang diambil menggunakan perangkat lunak Mission Planner. Data log akan di praproses untuk kemudian dilakukan sinkronisasi time sampling. Sinkronisasi dilakukan dengan mengikuti data sensor yang time sampling-nya paling besar. Hasil dari penelitian ini adalah data terbang dari sensor dan pulse width modulation output quadcopter yang telah disinkronisasi untuk menjadi data latih jaringan saraf tiruan propagasi balik.
\end{abstract}

Kata Kunci: data terbang quadcopter, jaringan saraf tiruan propagasi balik, quadcopter, sistem kendali

\begin{abstract}
Currently the control system that is popularly used in quadcopter is proportional, integral, derivative (PID) control because the algorithm is simple. But in its implementation, PID requires tuning parameters that are timeconsuming and prone to errors. Therefore, the backpropagation neural network control system for quadcopter is being developed widely because it offers better stabilization of unknown factors and sensor data that contains noise. However, the backpropagation neural network control system requires training data that is accurate and can represent all possible conditions for quadcopter flight. This study aims to obtain quadcopter flying data from log sensor and actuator data in quadcopter, namely gyroscope, accelerometer, magnetometer, barometer, GPS, and pulse width modulation output. Data retrieval is done by flying the quadcopter automatically with the predetermined start and final coordinates to fill in the flying log data. Flying log data is taken using the Mission Planner software. The log data will be preprocessed for synchronization of time sampling. Synchronization is based on the sensor data with the largest time sampling. The results of this study are flying data from sensors and pulse width modulation quadcopter output that has been synchronized to become backpropagation neural network training data.
\end{abstract}

Keywords: backpropagation neural network, control systems, quadcopter, quadcopter flying data.

\section{PENDAHULUAN}

Perkembangan teknologi khususnya di bidang elektronika dan instrumentasi telah menciptakan suatu inovasi berupa unmanned aerial vehicle (UAV). Menurut Dharmawan dan

\footnotetext{
${ }^{1}$ Departemen Ilmu Komputer, Fakultas Matematika dan Ilmu Pengetahuan Alam, Institut Pertanian Bogor, Jl. Meranti Wing 20 lv 5-6, Kampus IPB Dramaga, Dramaga, Bogor 16680;

*Penulis korespondensi: surel karlisa@apps.ipb.ac.id
} 
Firdaus (2012), UAV adalah sebuah perangkat yang dapat terbang dengan memanfaatkan hukum aerodinamika, baik dikendalikan dari jarak jauh dengan remote control atau secara otomatis dapat menavigasikan dirinya sendiri dengan autopilot. UAV dapat diaplikasikan untuk kebutuhan survey pertanian (Patel et al. 2013), patroli (Priambodo et al. 2012), fotografi margasatwa (Radiansyah et al. 2017), pencarian dan pertolongan (Naidoo et al. 2011), dan keperluan lainnya. Menurut Harista dan Nuryadi (2018) UAV dapat dibagi berdasarkan jumlah motor yang digunakan, salah satunya adalah quadcopter yang memiliki empat motor sebagai penggerak (Dharmawan dan Firdaus 2012). Menurut Setyawan et al. (2015) pengendalian quadcopter dilakukan dengan memvariasikan kecepatan pada masing-masing motor. Selain rotor yang dilengkapi baling-baling, quadcopter juga memiliki komponen lain untuk dapat beroperasi seperti unit kontrol utama yang mengatur proses komponen lain, baterai sebagai suplai daya, global positioning system (GPS) untuk menentukan geolocation, magnetometer untuk menentukan arah, barometer untuk menentukan ketinggian, giroskop untuk menentukan orientasi sikap, akselerometer untuk menentukan besaran akselerasi, radio telemetri untuk komunikasi data, serta penerima radio remote control.

Sistem yang mengatur pergerakan, keseimbangan, dan posisi quadcopter ketika terbang dapat disebut sebagai sistem kendali quadcopter. Saat ini, sistem kendali yang populer digunakan pada quadcopter adalah kendali proportional, integral, derivate (PID) karena algoritme tersebut sederhana (Burman 2016) dan memiliki respons yang cepat (Setyawan et al. 2015). Penelitian-penelitian lain yang telah dilakukan pada quadcopter sebelumnya antara lain penelitian dari Setyawan et al. (2015) tentang pengendalian sistem quadcopter menggunakan PID dan penelitian Heryanto et al. (2017) tentang kendali sikap (attitude) dan ketinggian (altitude) quadcopter menggunakan jaringan saraf tiruan berbasil skema direct inverse control.

Kendali PID, menurut Zulu dan John (2014), memiliki stabilisasi siap yang relatif bagus, waktu respon yang baik, dan hampir mendekati kondisi galat nol. Namun pada implementasinya, perlu dilakukan penyetelan variasi konstanta proporsional PID karena berpengaruh pada respons sistem (Bansal et al. 2012). Menurut Burman (2016), penyetelan parameter pada kendali PID dilakukan dengan cara trial dan error untuk menentukan nilai yang optimal. Proses ini memakan waktu dan rentan terhadap kesalahan. Karenanya, menurut Burman (2016) pendekatan berbasis jaringan saraf tiruan menggunakan teknik propagasi balik atau backpropagation neural network (BPNN) dapat menjadi alternatif kendali PID.

BPNN (Buscema 1998) merupakan keluarga luas dari jaringan saraf tiruan (JST), yang arsitekturnya terdiri atas berbagai lapisan yang saling berhubungan. BPNN mewakili jenis JST, yang algoritme pembelajarannya didasarkan pada teknik deepest-descent. Jika dijalankan dengan jumlah unit tersembunyi yang sesuai, teknik ini dapat meminimalkan kesalahan fungsi nonlinear dengan kompleksitas tinggi. Oleh karena itu, sistem kendali dengan BPNN dapat menawarkan stabilisasi yang lebih baik dari faktor-faktor yang tidak diketahui dan data sensor yang mengandung noise (Burman 2016).

BPNN telah diterapkan sebelumnya pada robot beroda (Priandana et al. 2018) yang kemudian ditingkatkan dengan memperbaiki kualitas data latih yang digunakan (Priandana et al. 2020). Berdasarkan kedua penelitian tersebut, pengembangan sistem kendali memerlukan data latih yang memiliki kualitas tinggi untuk mencapai performa yang diharapkan. Pada kasus quadcopter, selain data latih yang akurat dan baik, data latih juga harus mewakili seluruh kemungkinan kondisi terbang quadcopter. Kondisi terbang ini antara lain meliputi manuver/gerakan, orientasi sikap dalam menjaga keseimbangan, pengarahan heading, dan kecepatan putaran rotor baling-baling yang dilakukan quadcopter ketika menjalankan misi menuju titik tujuan.

Oleh karena itu, penelitian ini dilakukan untuk mengakusisi data terbang quadcopter dari data $\log$ sensor dan aktuator yang ada di quadcopter (giroskop, akselerometer, magnetometer, barometer, GPS, dan pulse width modulation output (PWM)). Penelitian dilakukan dengan batasan berikut, yaitu pengambilan data terbang menggunakan quadcopter yang dirakit oleh peneliti, data terbang yang digunakan merupakan data perjalanan quadcopter dari koordinat 
awal ke koordinat tujuan yang telah ditentukan, lingkungan penerbangan dilakukan pada ruang terbuka dengan permukaan datar tanpa ada rintangan. dan dilakukan praproses data terbang untuk disiapkan menjadi data latih BPNN. Data yang dikumpulkan pada penelitian ini akan menjadi data latih pada metode BPNN yang akan dilaksanakan pada penelitian selanjutnya.

\section{METODE}

Penelitian ini terdiri atas 6 tahapan. Tahapan-tahapan yang dilakukan pada penelitian ini dapat dilihat pada Gambar 1.

\section{Perakitan Quadcopter}

Pada tahap ini, komponen-komponen quadcopter dirakit hingga terintegrasi satu dengan lainnya menjadi sebuah quadcopter yang utuh. Komponen perangkat keras yang digunakan adalah flight controller Radiolink Pixhawk, modul GPS UBLOX NEO-7M, RC receiver Turnigy 9X 8C v2, baterai Turnigy 2200mAh 25-30C, 4 ESC Simonk 30A, 4 brushless motor A2212/13T 1000KV, $2433 \mathrm{Mhz}$ telemetry radio 500mA, RC PPM encoder, power module, safety switch, buzzer, F450 quadcopter frame, 4 propeler, dan 4 propeler shield. Selain itu, perangkat keras pendukung berupa remote control Turnigy TGY 9x juga digunakan untuk mengendalikan quadcopter. Diagram koneksi antar komponen sistem quadcopter diilustrasikan dalam diagram blok sistem pada Gambar 2.

\section{Pengecekan Fungsionalitas Komponen}

Pengecekan fungsionalitas komponen dilakukan untuk memastikan seluruh komponen berfungsi secara normal. Pengecekan dilakukan pada delapan hal utama yang meliputi:

- Pengecekan flight controller yang menyala ketika diberi daya dari beterai maupun laptop/PC.

- Pengecekan komunikasi antara flight controller dan komputer menggunakan kabel universal serial bus (USB) tipe mikro dan radio telemetri.

- Pengecekan fungsi flight controller untuk mendeteksi sensor dan komponen lain yang terhubung.

- Pengecekan giroskop dan akselerometer untuk mendeteksi perubahan orientasi sudut, gerakan, dan percepatan.

- Pengecekan barometer untuk mendeteksi perubahan ketinggian.

- Pengecekan remote control untuk menerima masukan sinyal dari remote control.

- Pengecekan modul GPS untuk menangkap sinyal satelit GPS dan penguncian lokasi quadcopter.

- Pengecekan fungsi putaran motor dengan daya dari electronic speec control (ESC) melalui sinyal yang diberikan dari flight controller.

\section{Konfigurasi, Implementasi, dan Kalibrasi Sensor pada Quadcopter untuk Penerbangan Otomatis}

Pada tahap ini, perangkat lunak Mission Planner digunakan untuk konfigurasi flight controller dan kalibrasi sensor. Selanjutnya, konfigurasi untuk terbang otomatis diatur berdasarkan koordinat awal dan tujuan. Pada penelitian ini akan dilakukan misi penerbangan dari dekat tribun di lapangan gimnasium Institut Pertanian Bogor hingga lurus sejauh \pm 100 meter ke tepi lapangan. Rute penerbangan lurus ini dipilih karena paling senderhana dan tidak membutuhkan banyak manuver yang cepat menghabiskan baterai. Setelah konfigurasi dan kalibrasi selesai, misi penerbangan otomatis sudah dapat dilakukan. 


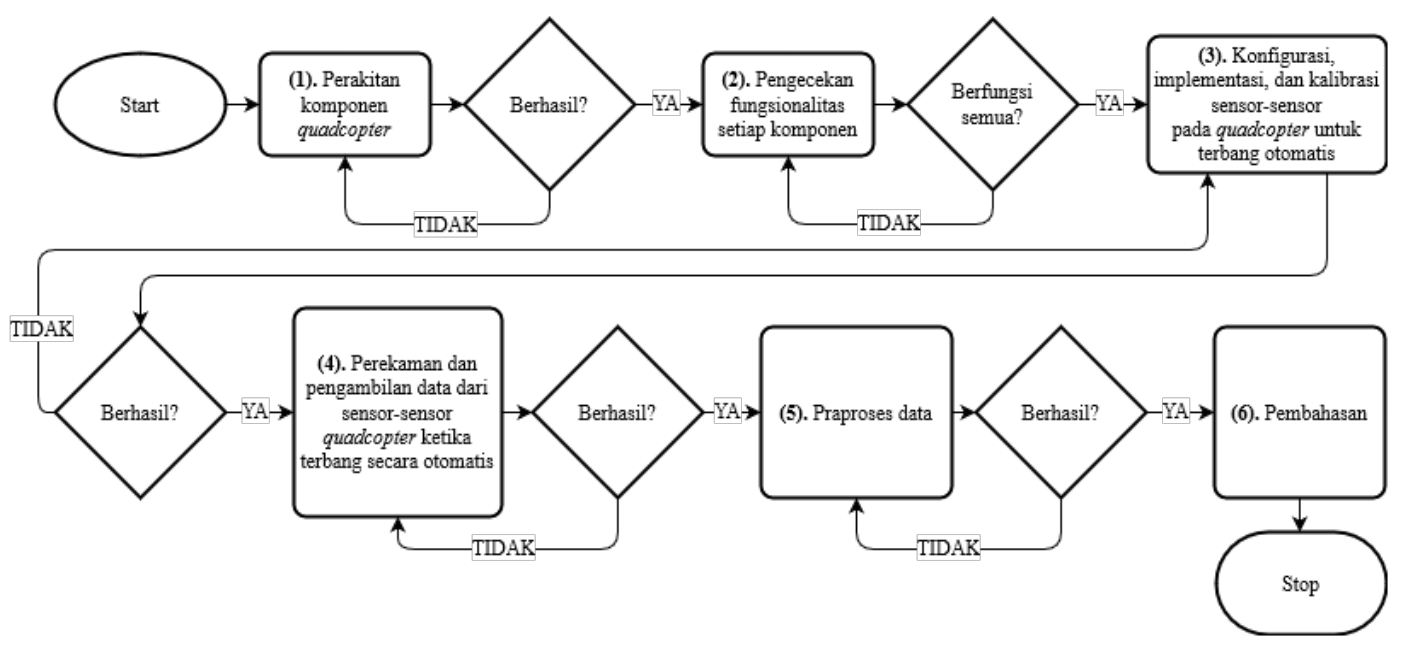

Gambar 1 Tahapan penelitian.

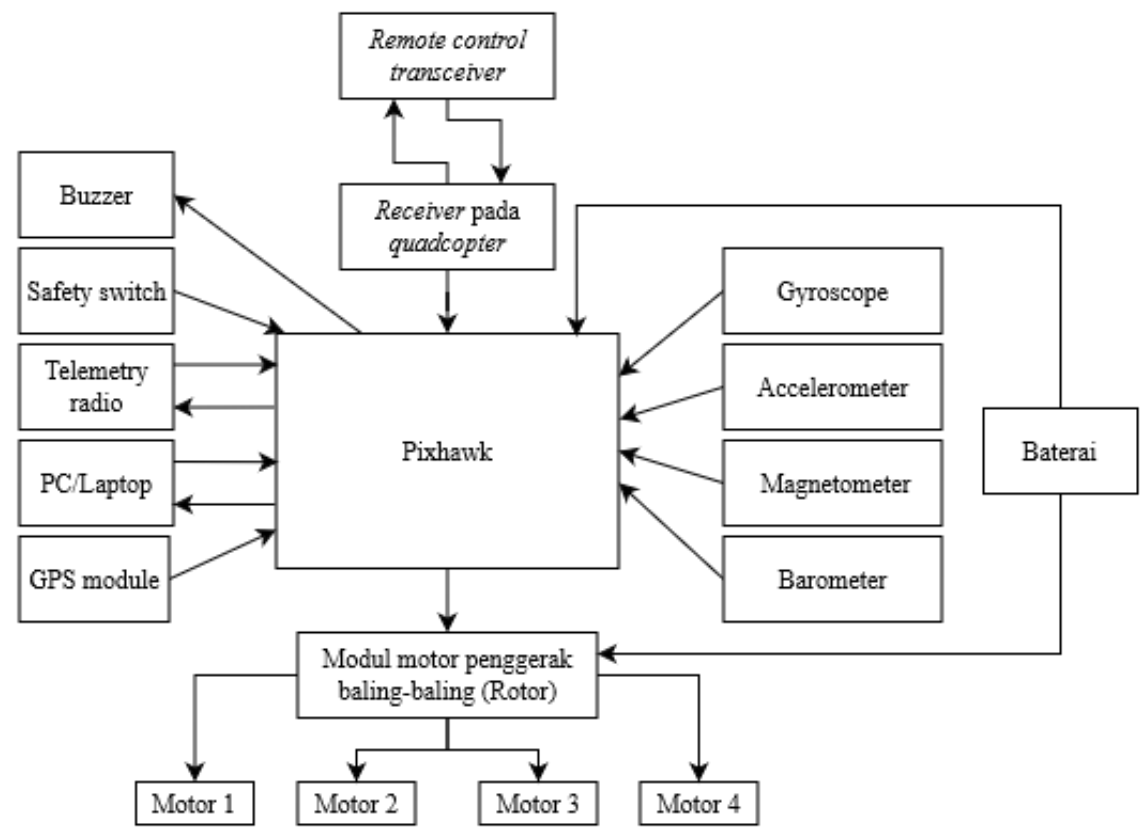

Gambar 2 Diagram blok sistem quadcopter.

\section{Perekaman dan Akuisisi Data}

Ketika quadcopter memulai misi secara otomatis, quadcopter akan melakukan pencatatan data dari sensor dan PWM secara berkala. Catatan ini disebut data flash log yang tersimpan dalam media penyimpanan kartu MicroSD. Setelah berhasil menyelesaikan misi penerbangan, data flash log dapat diunduh menggunakan perangkat lunak Mission Planner melalui kabel yang menghubungkan flight controller dengan komputer.

\section{Praproses Data}

Data $\log$ akan dipraproses dengan memotong data sesuai kebutuhan, membuang atribut yang tidak diperlukan, dan mensinkronisasi data ke data yang memiliki time sampling paling besar menggunakan program $\mathrm{C}++$ yang dibuat untuk penelitian ini.

\section{Pembahasan}

Data yang telah diolah ditampilkan dalam bentuk grafik dan tabel, kemudian dianalisis dari segi hubungan antara trend data dengan pengamatan di lapangan saat pengambilan data. Hal ini dilakukan untuk mempermudah justifikasi apabila data telah digunakan untuk memodelkan sistem dalam sistem kendali, terutama apabila ada ketidaksesuaian. 


\section{HASIL DAN PEMBAHASAN}

\section{Perakitan}

Hasil dari perakitan quadcopter dapat dilihat pada Gambar 3. Pada rangka f450, terdapat dua lapisan. Lapisan digunakan untuk memasang flight controller Pixhawk, sedangkan lapisan atas digunakan untuk memasang baterai. Modul GPS, buzzer, radio telemetri, dan safety switch dipasangkan di pangkal dari keempat lengan quadcopter. Penerima remote control dipasangkan di depan quadcopter pada lapisan bawah. Keempat propeler dan motor dipasangkan pada ujung-ujung lengan quadcopter dan modul ESC dipasangkan di bawah keempat lengan quadcopter.

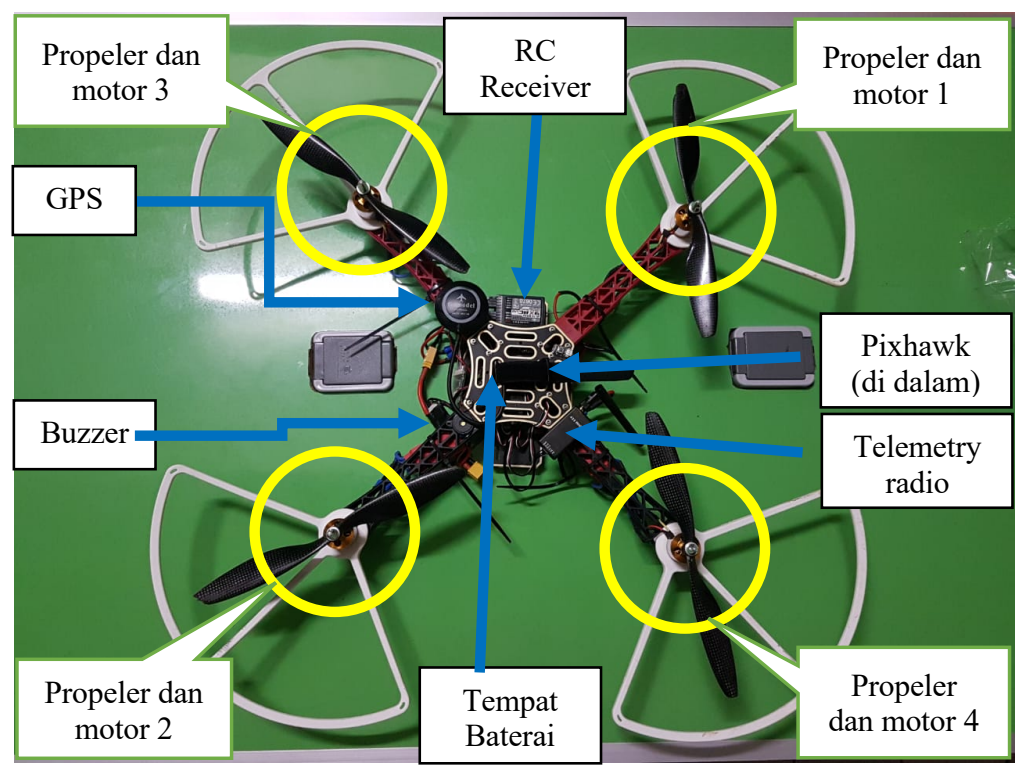

Gambar 3 Hasil dan detail komponen quadcopter setelah perakitan.

\section{Pengambilan dan Praproses Data Terbang}

Quadcopter diterbangkan otomatis sesuai misi yang diberikan untuk melakukan logging data penerbangan. Setelah menjalankan misi, dataflash log dari quadcopter diunduh dan diekstraksi. Hasil ekstraksi dataflash log berupa data terbang mentah yang memiliki empat ratus empat atribut. Dari seluruh atribut tersebut, empat puluh atribut yang menjadi data masukan dari sensor dan keluaran dari quadcopter dipilih berdasarkan dokumentasi Ardupilot (ardupilot.org). Atribut-atribut tersebut dikelompokkan menjadi sembilan kelompok yang dapat dilihat pada Tabel 1. Masing-masing atribut memiliki perbedaan rentang waktu perekaman data dengan data selanjutnya yang disebabkan kecepatan pembacaan data pada masing-masing sensor tidak sama. Rentang waktu pada kecepatan pembacaan data ini disebut sebagai time sampling.

Pengambilan dan praproses dilakukan menggunakan program $\mathrm{C}++$ yang dibuat. Program $\mathrm{C}++$ tersebut juga membuang record yang tidak memiliki salah satu dari ke 9 kelompok atribut dan memilih kelompok atribut yang terekam lebih dari satu kali pada record yang sama dengan selisih waktu rekam paling kecil terhadap kelompok atribut yang memiliki time sampling paling besar. Proses memilih kelompok atribut yang terekam lebih dari satu kali pada record yang sama ini dapat disebut sebagai sinkronisasi time sampling. Hal ini dilakukan karena time sampling dari beberapa kelompok atribut tidak sama sehingga proses sinkronisasi diperlukan agar jumlah dan rentang waktu setiap kelompok atribut menjadi sama.

Time sampling dari 9 kelompok atribut data terbang dapat dikelompokkan menjadi tiga, yaitu dengan time sampling paling besar adalah GPS dan GPA dengan 0.2 detik, time sampling yang paling kecil adalah IMU dan IMU 2 dengan 0.04 detik, dan sisanya memiliki time sampling 0.1 detik. Pada data terbang raw, kelompok atribut yang frekuensi 
Tabel 1 Atribut-atribut input dan output sistem quadcopter

\begin{tabular}{|c|c|c|}
\hline Kelompok Atribut & Nama Atribut & Deskripsi \\
\hline \multirow[t]{3}{*}{ Attitude } & Roll & $\begin{array}{l}\text { Sudut roll quadcopter yang sebenarnya dalam derajat (roll kiri } \\
\text { negatif, kanan positif) }\end{array}$ \\
\hline & Pitch & $\begin{array}{l}\text { Sudut pitch quadcopter yang sebenarnya dalam derajat (pitch maju } \\
\text { negatif, pitch kembali positif) }\end{array}$ \\
\hline & Yaw & Arah quadcopter yang sebenarnya dalam derajat dengan $0=$ utara \\
\hline \multirow{2}{*}{$\begin{array}{l}\text { Control, Throttle } \\
\text { and altitude } \\
\text { information (CTUN) }\end{array}$} & Barometer Altitude & $\begin{array}{l}\text { Barometer Altitude: Ketinggian di atas tanah berdasarkan barometer } \\
\text { dalam meter }\end{array}$ \\
\hline & Climb Rate & Climb Rate: Accelerometer + perkiraan barometer dalam $\mathrm{cm} / \mathrm{s}$ \\
\hline \multirow{4}{*}{$\begin{array}{l}\text { Global positioning } \\
\text { system (GPS) }\end{array}$} & Latitude & Latitude berdasarkan GPS \\
\hline & Longitude & Longitude berdasarkan GPS \\
\hline & Kecepatan Horizontal & Kecepatan gerak horizontal dalam m/s \\
\hline & HDop & Ukuran presisi GPS ( 1.5 baik, $>2.0$ tidak begitu baik) \\
\hline \multirow[t]{2}{*}{$\begin{array}{l}\text { Global position } \\
\text { accuracy (GPA) }\end{array}$} & HAcc & $\begin{array}{l}\text { Akurasi horizontal seperti yang dilaporkan oleh modul GPS dalam } \\
\text { meter }\end{array}$ \\
\hline & SAcc & $\begin{array}{l}\text { Akurasi kecepatan seperti yang dilaporkan oleh modul GPS dalam } \\
\text { meter }\end{array}$ \\
\hline Inertial & GyrX, GyrY, GyrZ & Nilai raw tingkat rotasi gyro dalam deg/s untuk sumbu $x, y$ dan $z$ \\
\hline $\begin{array}{l}\text { measurement unit } \\
\text { (IMU) }\end{array}$ & AccX, & loolomeidslom \\
\hline \multirow{2}{*}{$\begin{array}{l}\text { Magnetometer } \\
\text { (Kompas) }\end{array}$} & MagX, MagY, MagZ & Nilai raw medan magnet untuk sumbu $x, y$ dan $z$ \\
\hline & OfsX, OfsY, OfsZ & $\begin{array}{l}\text { Nilai raw offset magnetik (hanya akan berubah jika parameter } \\
\text { COMPASS_LEARN adalah 1) }\end{array}$ \\
\hline $\begin{array}{l}\text { RC output } \\
\text { (RCOUT) }\end{array}$ & $\mathrm{C} 1, \mathrm{C} 2, \mathrm{C} 3, \mathrm{C} 4$ & $\begin{array}{l}\text { C1, C2, dll: PWM command dikirim dari flight controller ke } \\
\text { ESC/motor }\end{array}$ \\
\hline
\end{tabular}

ketidaklengkapannya tinggi pada sebuah record adalah GPS dan GPA karena memiliki time sampling paling besar dan kelompok atribut yang terekam lebih dari satu kali pada record yang sama adalah IMU dan IMU 2 karena memiliki time sampling paling kecil.

Setelah praproses, setiap kelompok atribut sudah memiliki jumlah yang sama dan setiap record sudah memiliki tepat satu dari setiap kelompok atribut. Hasil data pada kelompok atribut attitude diilustrasikan pada Gambar 4. Pada gambar grafik tersebut, dapat dilihat grafik dari nilai masing-masing sudut roll, pitch, dan yaw. Fluktuasi grafik pada masing-masing sudut dimulai pada detik ke 27 yang menandakan sikap quadcopter mulai berubah. Perubahan yang paling signifikan terlihat ada pada kurva yaw yang menunjukkan perubahan arah heading quadcopter seiring waktu dalam derajat sudut.

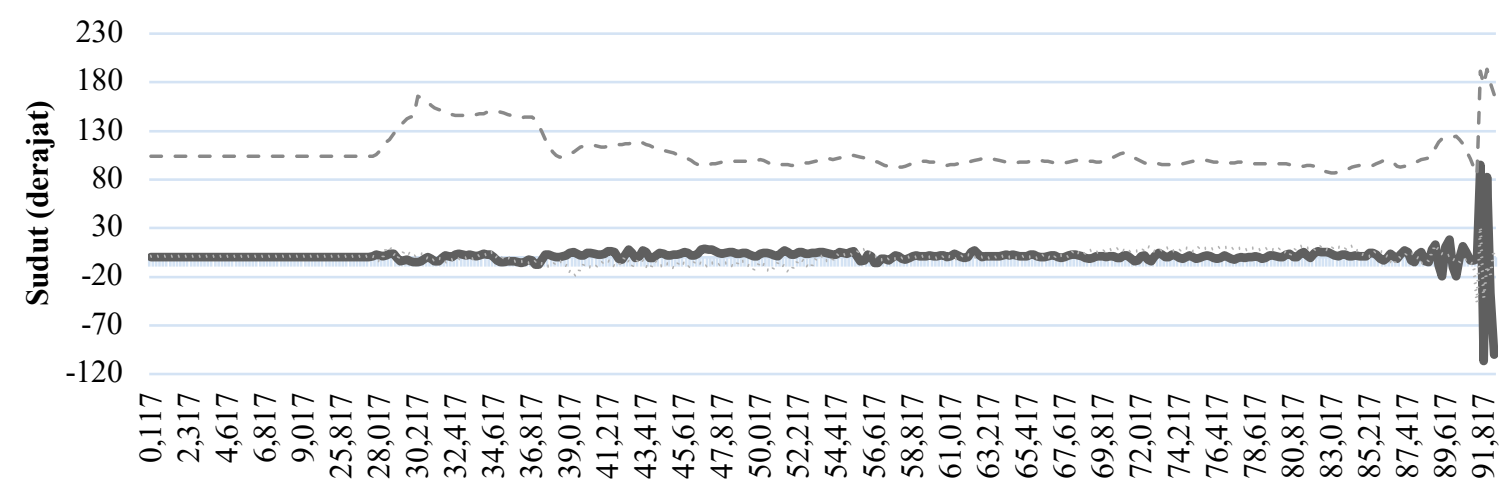

Waktu (detik)

$\longrightarrow$ Roll …….... Pitch - - - Yaw

Gambar 4 Grafik nilai sikap (attitude) pada data terbang yang telah dipraproses.

Hasil data pada kelompok atribut barometer diilustrasikan pada Gambar 5. Pada gambar grafik tersebut, dapat dilihat grafik dari nilai ketinggian dari quadcopter. Nilai pada grafik mulai menaik pada detik ke-27 yang menadakan quadcopter mulai terbang. Quadcopter mulai 
pergi ke koordinat tujuan ketika nilai altitude mencapai ketinggian telah mencapai 10 meter sesuai setelan. Namun di tengah-tengah, kurva menaik keketinggian 15 meter. Kenaikan ketinggian ini terjadi ketika quadcopter telah sampai di koodinat tujuan dan akan kembali menuju koordinat awal. Kenaikan tersebut terjadi bukan dari setelan yang telah dilakukan. Pada kondisi ini, quadcopter dianggap mengalami masalah ketika mempertahankan ketinggian sehingga quadcopter menambah ketinggian agar tidak terjatuh. Pada akhirnya, grafik kurva menurun menandakan quadacopter menurunkan ketinggian untuk mendarat.

Hasil data pada kelompok atribut GPS diilustrasikan menjadi tiga grafik berdasarkan atribut latitude, longitude, dan kecepatan horizontal. Grafik data latitude dan longitude ditunjukkan pada Gambar 6 dan 7. Pada kedua grafik tersebut, dapat dilihat perubahan nilai latitude lebih besar dari pada perubahan nilai longitude. Hal ini terjadi karena pada misi yang dilakukan quadcopter, koordinat yang dituju dari posisi awal hanya membentuk pergerakan pada garis latitude sehingga nilai longitude tidak berubah signifikan. Perubahan kurva pada latitude yang signifikan menggambarkan bahwa quadcopter bergerak lurus.

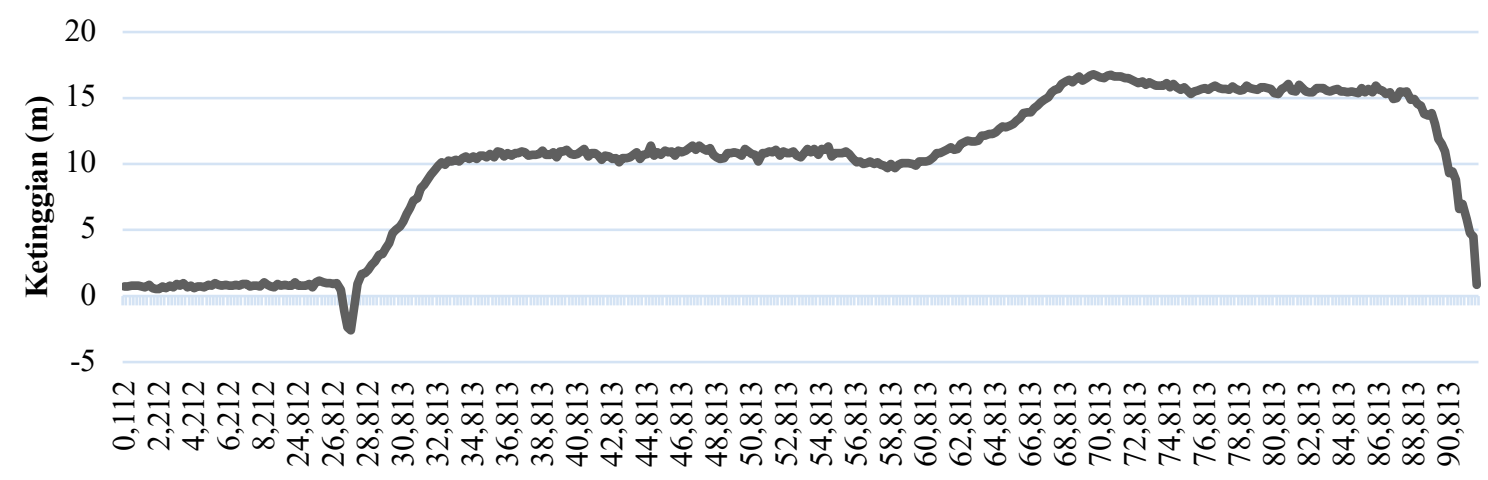

Waktu (detik)

Gambar 5 Grafik nilai barometer pada data terbang yang telah dipraproses.

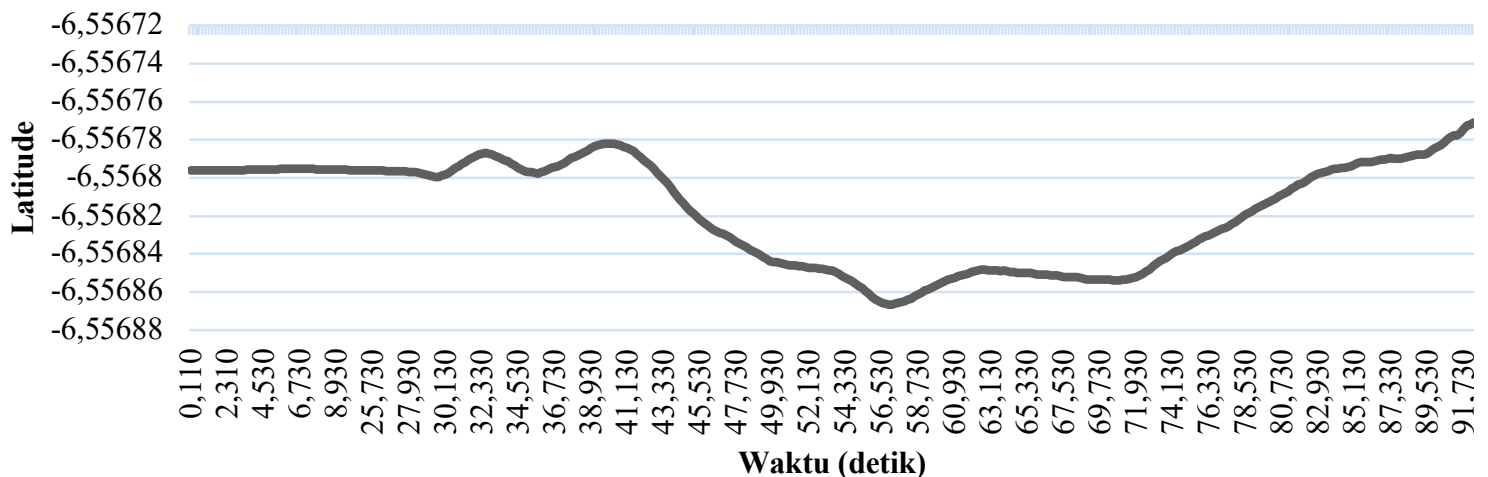

Gambar 6 Grafik nilai latitude pada data terbang yang telah dipraproses.

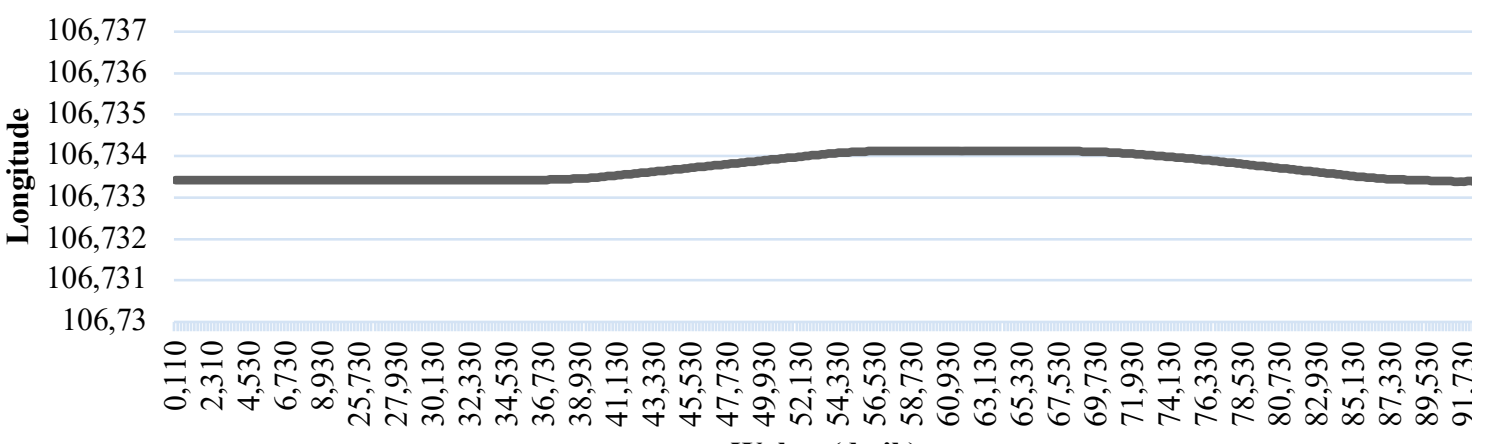

Waktu (detik)

Gambar 7 Grafik nilai longitude pada data terbang yang telah dipraproses. 
Grafik data kecepatan horizontal (Gambar 8) menunjukkan dua lembah dan dua puncak. Lembah pertama menunjukkan keadaan ketika quadcopter belum bergerak. Puncak pertama menunjukkan quadcopter sedang bergerak menuju koordinat yang dituju dengan rata-rata kecepatan 4 sampai $5 \mathrm{~m}$ /detik. Lembah kedua adalah kondisi ketika quadcopter sudah sampai di tujuan. Puncak kedua menunjukkan quadcopter bergerak kembali menuju posisi awal.

Gambar 9 memperlihatkan atribut GPA. HDop adalah akronim dari atribut horizontal dilution of precision yang merepresentasikan tingkat presisi posisi data horizontal dari GPS. VDop adalah akronim dari atribut vertical dilution of precision yang merepresentasikan tingkat presisi posisi data vetikal dari GPS. HAcc adalah akronim dari horizontal accuracy yang merepresentasikan tingkat akurasi data bidang horizontal dari GPS. VAcc adalah akronim dari vertical accuracy yang merepresentasikan tingkat akurasi data pada bidang vertikal dari GPS. SAcc adalah akronim dari speed accuracy yang merepresentasikan tingkat akurasi data kecepatan dari GPS.

Hasil data pada kelompok atribut IMU dan IMU 2 masing-masing diilustrasikan menjadi empat grafik, yaitu grafik giroskop sebanyak dua unit (Gambar 9 dan 10) dan akselerometer sebanyak dua unit (Gambar 11 dan 12). Grafik giroskop merepresentasikan data tingkat rotasi ketiga sudut $x, y$, dan $z$ pada quadcopter selama misi penerbangan dalam satuan derajat/detik. Grafik akselerometer menunjukkan percepatan masing-masing sudut $\mathrm{x}, \mathrm{y}$, dan $\mathrm{z}$ pada quadcopter selama misi penerbangan dalam satuan meter/detik ${ }^{2}$.

Pada grafik akselerometer dapat dilihat bahwa kurva sudut X membentuk pola lembah landai kemudian puncak landai. Lembah yang landai terjadi karena sumbu X quadcopter bergerak maju. Kondisi ini menyebabkan sumbu $\mathrm{X}$ akan mendapat percepatan karena pergerakan maju. Nilai negatif pada kondisi ini menandakan quadcopter mendapat percepatan dari arah sumbu $\mathrm{X}$ positif atau arah heading quadcopter. Kemudian, kurva puncak landai menandakan quadcopter sedang melakukan gerakan mundur ke posisi awal. Kondisi ini akan membuat sumbu $\mathrm{X}$ negatif atau bagian belakang quadcopter akan mendapat percepatan sehingga nilainya positif. Sumbu $\mathrm{Z}$ quadcopter yang terus berada pada rentang negatif 10 menandakan percepatan gravitasi bumi yang diterima secara terus menerus selama misi berlangsung.

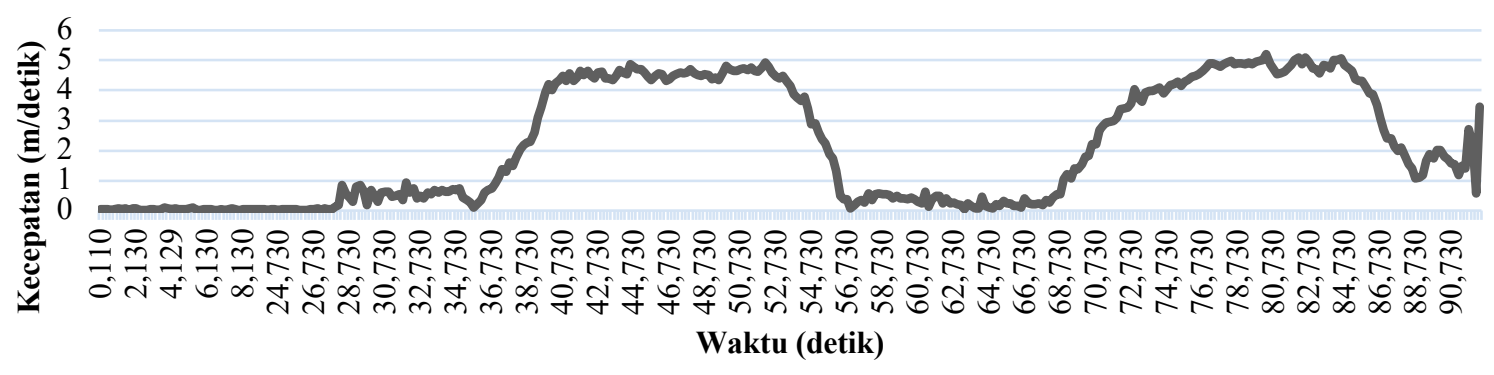

Gambar 8 Grafik nilai kecepatan horizontal pada data terbang yang telah dipraproses.

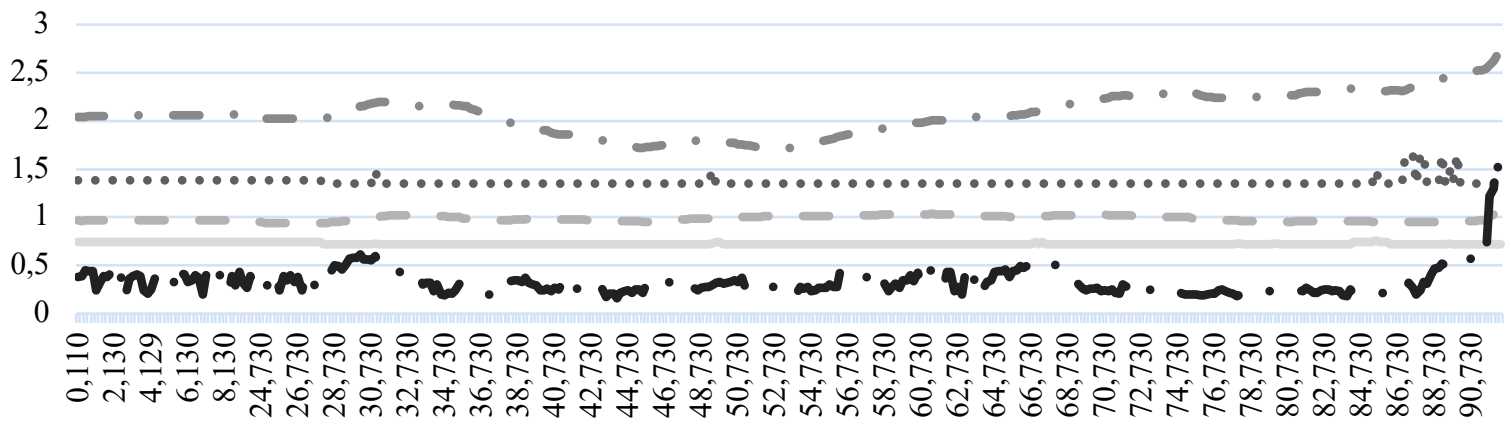

Waktu (detik)

$\longrightarrow$ HDop... . VDop -- HAcc - - VAcc - SAcc

Gambar 9 Grafik nilai GPA pada data terbang yang telah dipraproses. 


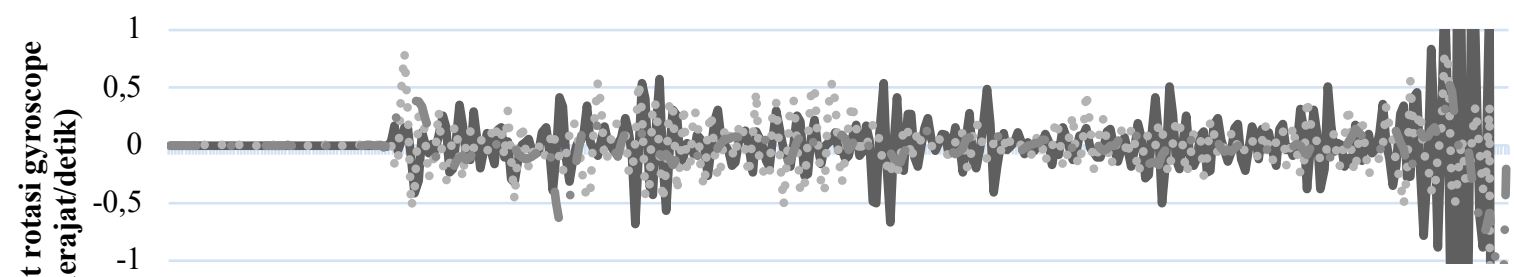

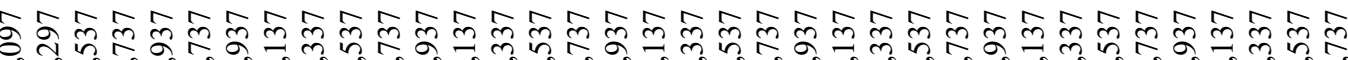

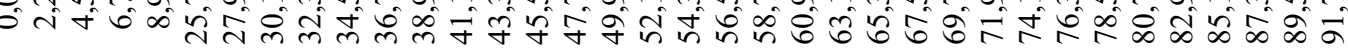

\section{Waktu (detik)}

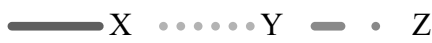

Gambar 10 Grafik nilai sensor giroskop pertama pada data terbang yang telah dipraproses.

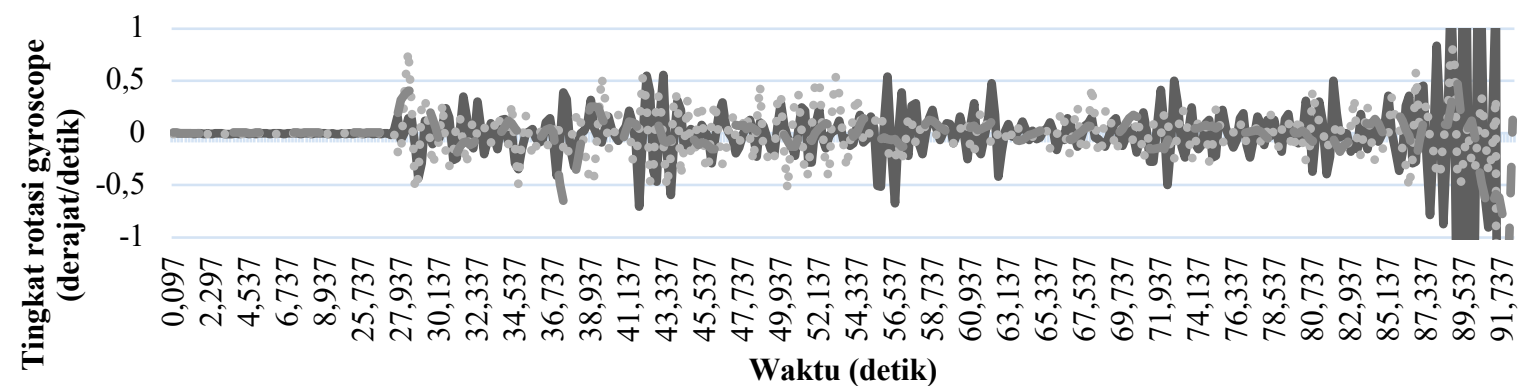

Waktu (detik)

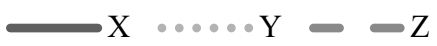

Gambar 11 Grafik nilai sensor giroskop kedua pada data terbang yang telah dipraproses.

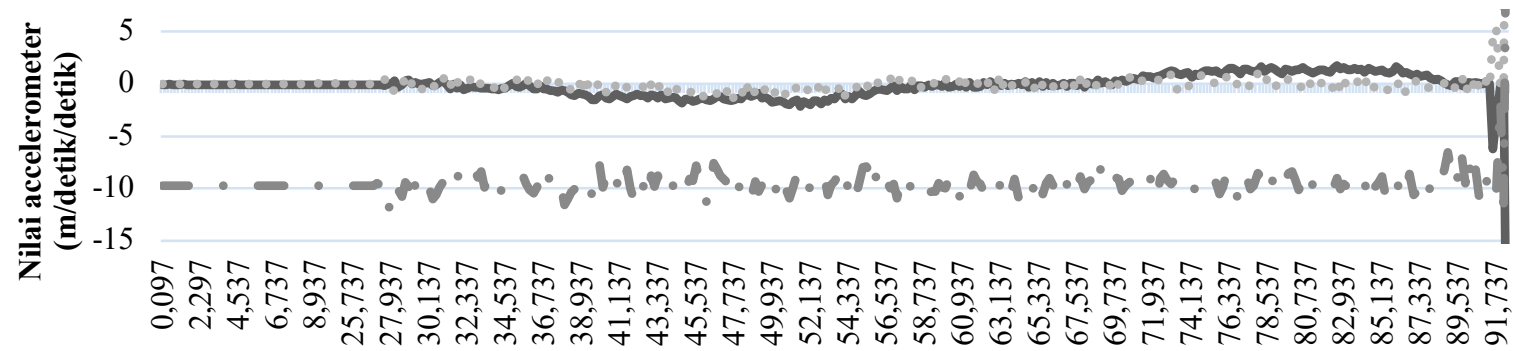

Waktu (detik)

$\longrightarrow \mathrm{X} \cdots \mathrm{Y}-\cdot \mathrm{Z}$

Gambar 12 Grafik nilai sensor akselerometer pertama pada data terbang yang telah dipraproses.

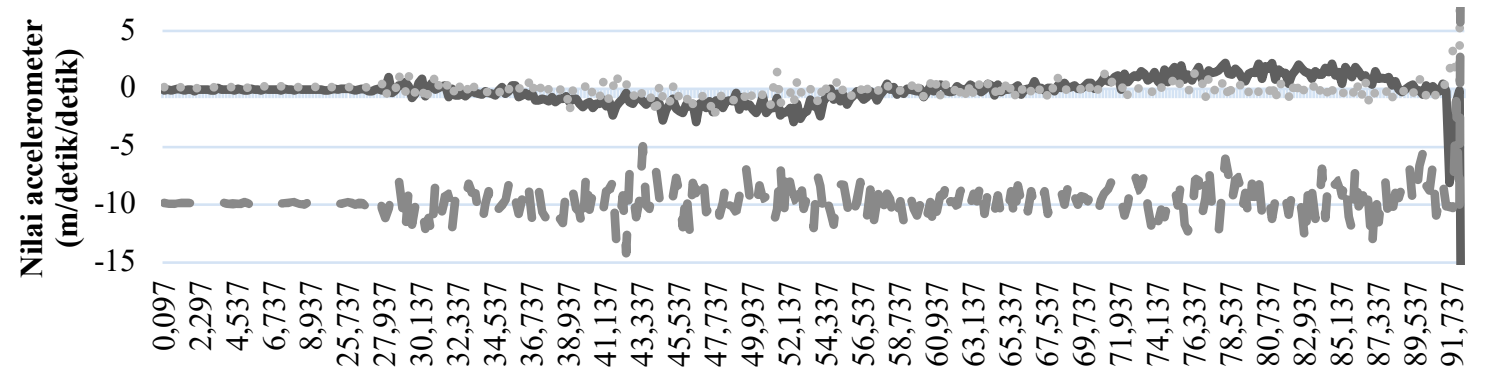

Waktu (detik)

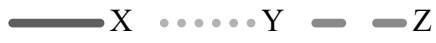

Gambar 13 Grafik nilai sensor akselerometer kedua pada data terbang yang telah dipraproses.

Hasil akuisisi data pada kelompok atribut magnetometer pertama dan magnetometer kedua masing-masing diilustrasikan oleh grafik pada Gambar 14 dan 15. Pada gambar grafik 
tersebut, dapat dilihat grafik dari nilai setiap atribut MagX, MagY, MagZ, OffsetX, OffsetY, dan OffsetZ. Atribut Mag merupakan atribut medan gaya pada sumbu $x, y$, dan $z$, sedangkan atribut Offset merupakan nilai dari atribut offset pada setiap sumbu $x, y$, dan $z$.

Hasil data pada kelompok atribut PWM output diilustrasikan oleh grafik pada Gambar 16. Pada gambar grafik tersebut, dapat dilihat grafik dari nilai setiap atribut, yaitu channel 1 , channel 2, channel 3, dan channel 4. Keempat atribut channel tersebut adalah PWM keluar yang akan masuk ke masing-masing motor pada quadcopter.

Hasil dari semua atribut data terbang tersebut setelah proses praproses berjumlah 389 record. Semua atribut telah melewati proses praproses dan disinkronisasi dengan time sampling kelompok atribut GPS yaitu 0.2 detik. Pada hasil data ini, terdapat sedikit ketidaksesuaian terhadap kondisi seharusnya. Hal ini disebabkan pada saat pengambilan data terbang, proses descend saat misi terbang dilakukan terganggu karena mengalami kecelakaan. Akan tetapi, hasil akhir data ini tetap dianggap sudah bisa mewakili hampir seluruh kemungkinan kondisi terbang dari quadcopter untuk menjadi data latih BPNN.

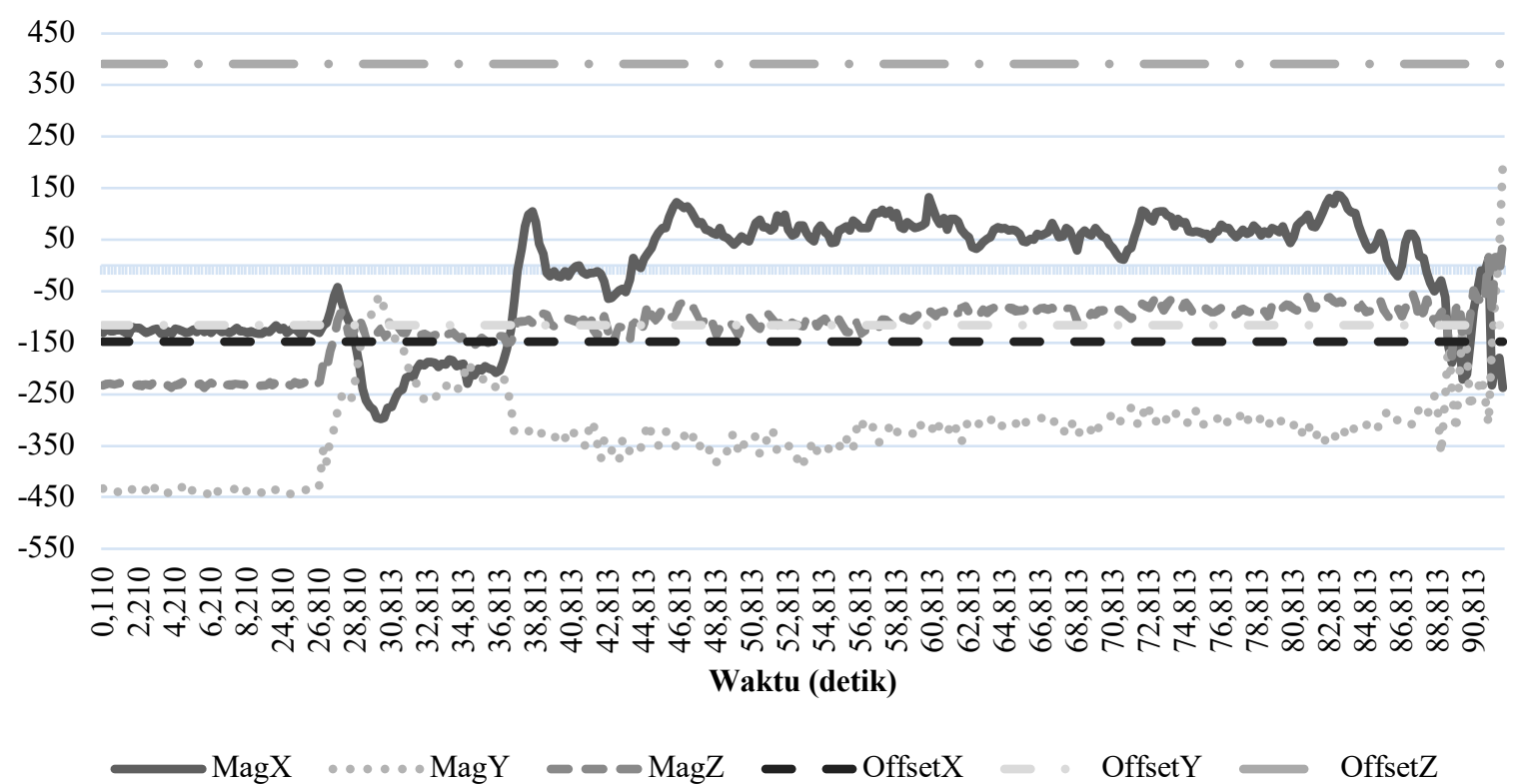

Gambar 14 Grafik nilai sensor magnetometer pertama pada data terbang yang telah dipraproses.

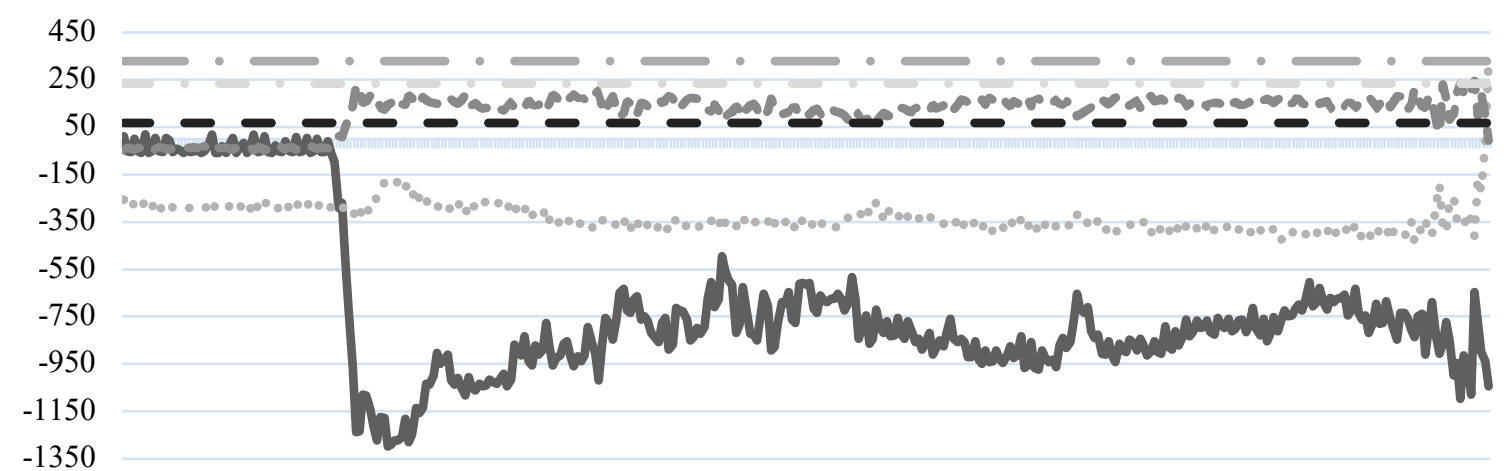

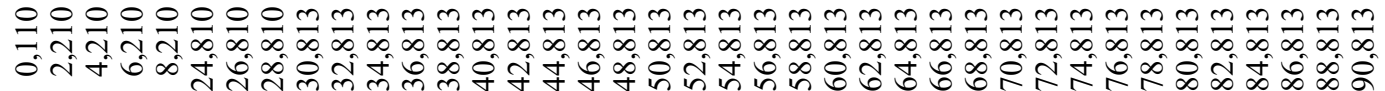
Waktu (detik)

$\longrightarrow$ MagX $\ldots . . M \operatorname{MagY}-\infty$ MagZ - OffsetX - OffsetY OffsetZ

Gambar 15 Grafik nilai sensor magnetometer kedua pada data terbang yang telah dipraproses. 


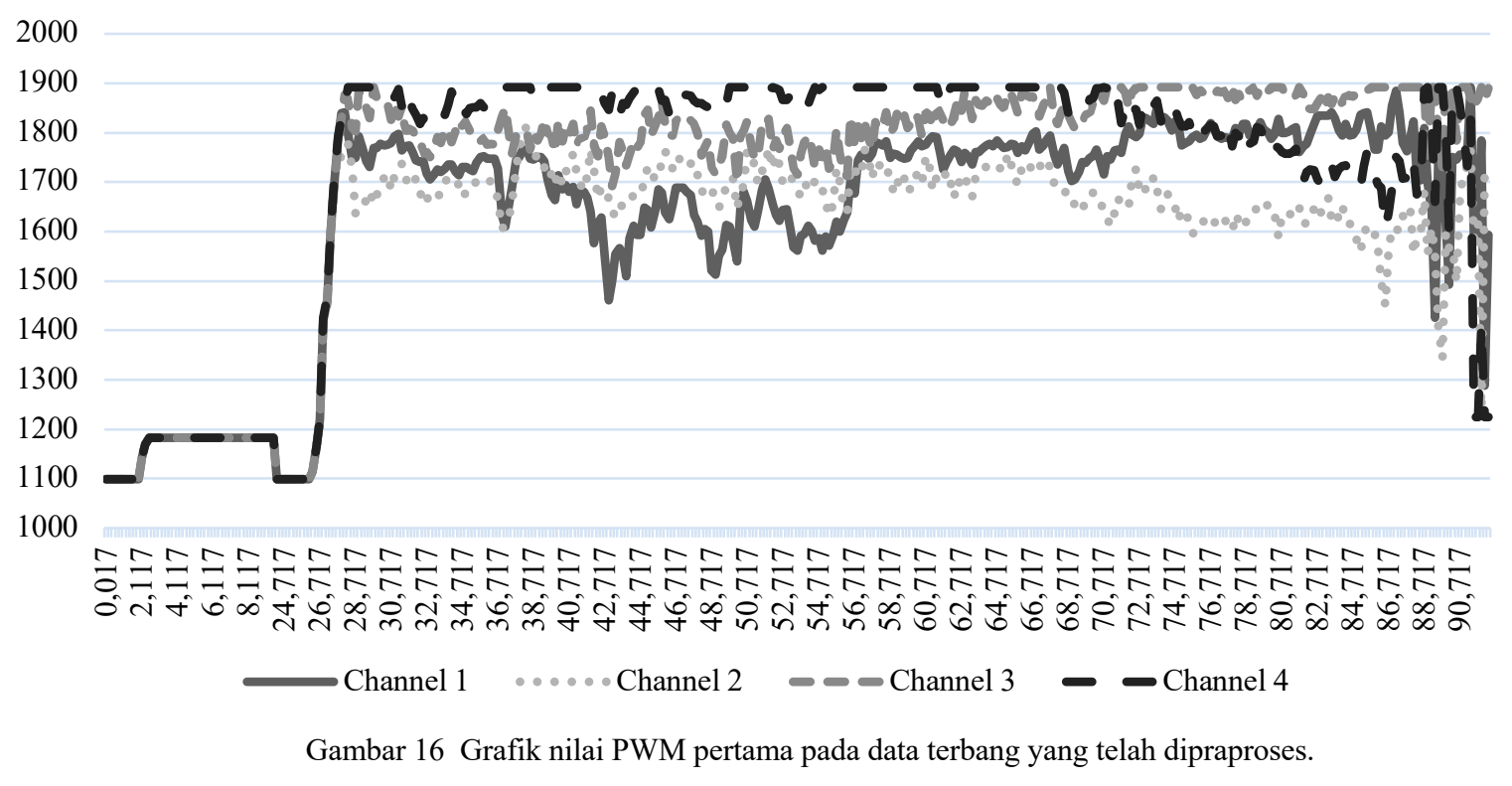

\section{SIMPULAN}

Pengambilan dan praproses data terbang quadcopter telah berhasil dilakukan. Hasil data terbang disinkronisasi menggunakan kelompok atribut dengan time sampling terbesar, yaitu sebesar 0.2 detik. Data akhir yang dihasilkan berjumlah 389 record. Hasil akhir data ini dianggap sudah bisa mewakili hampir seluruh kemungkinan kondisi terbang dengan rute lurus pada quadcopter karena atribut-atribut data hasil akhir dapat merepresentasikan kondisi quadcopter setiap waktu ketika menjalankan rute tersebut. Hasil akhir ini sudah dapat menjadi data latih BPNN untuk rute terbang lurus.

\section{UCAPAN TERIMA KASIH}

Terima kasih penulis ucapkan kepada Direktorat Riset dan Pengabdian Masyarakat Direktorat Jenderal Penguatan Riset dan Pengembangan Kementerian Riset, Teknologi, dan Pendidikan Tinggi yang telah membiayai penelitian ini melalui hibah Penelitian Dasar Unggulan Pergurutan Tinggi Tahun 2018 yang berjudul Pengembangan Collaborative Robot Menggunakan Kecerdasan Komputasional untuk Pencarian dan Penyelamatan Bencana Longsor. Terima kasih juga penulis ucapkan pada Departemen Ilmu Komputer yang telah membiayai secara parsial perangkat yang digunakan pada penelitian ini.

\section{DAFTAR PUSTAKA}

Bansal HO, Sharma R, Shreeraman PR. 2012. PID Controller Tuning Techniques: A Review. JCET. 2:168-176.

Burman P. 2016. Quadcopter Stabilization with Neural Network [tesis]. Austin(US). University of Texas at Austin.

Buscema M. 1998. Back Propagation Neural Networks. Substance Use \& Misuse. 33(2): 23370 .

Dharmawan A, Firdaus IN. 2012. Purwarupa Sistem Otomasi Terbang Landas dan Mendarat Quadcopter. IJEIS. 2(1):87-96.

Harista AF, Nuryadi S. 2018. Sistem Navigasi Quadcopter dan Pemantauan Udara. JURNAL TeknoSAINS Seri Teknik Elektro. 1(1). 
Heryanto MA, Suprijono H, Suprapto BY, dan Kusumoputro B. 2017. Attitude and altitude control of a quadcopter using neural network besed direct invers control scheme. Advanced Science Letters.

Priandana K, Abiyoga I, Daini AN, Hardhienata MK. 2020. Improvement of data accuracy on backpropagation neural network-based automatic control system for wheeled robot. Di dalam: 2020 International Conference on Smart Technology and Applications (ICoSTA); 20 Feb 2020, Surabaya, Indonesia. Hlm 1-5. IEEE.

Priandana K, Abiyoga I, Wahjuni S, Hardhienata M, Buono A. 2018. Development of computational intelligence-based control system using backpropagation neural network for wheeled robot. Di dalam: 2018 International Conference on Electrical Engineering and Computer Science (ICECOS); 2 Oktober 2018, Pangkal Pinang, Indonesia. hlm 101106. IEEE.

Naidoo Y, Stopforth R, Bright G. 2011. Development of an UAV for search \& rescue applications. Di dalam: IEEE Africon '11; 2011 Sep 13-15; Livingstone, Zambia. Livingstone (ZM): IEEE. hlm. 1-6.

Patel PN, Patel MA, Faldu RM, Dave YR. 2013. Quadcopter for Agricultural Surveillance. Advance in Electronic and Electric Engineering. 3(4):427-432.

Priambodo AS, Astrowulan K, Susila J. 2012. Perancangan dan Implementasi Sistem Kendali PID untuk Pengendalian Gerakan Hover pada UAV Quadcopter. POMITS. 1(1):1-5.

Radiansyah S, Kusrini MD, Prasetyo LB. 2017. Quadcopter Applications for Wildlife Monitoring. IOP Conference Series: Earth and Environmental Science. 54.

Setyawan GE, Setiawan E, Kurniawan W. 2015. Sistem Kendali Ketinggian Quadcopter Menggunakan PID. JTIIK. 2(2):125-131.

Zulu A, John S. 2014. A Review of Control Algorithms for Autonomous Quadrotors. OJAppS. 4:547-556. 